\title{
Baseline Research for Action: Adolescent Alcohol Consumption in Los Palacios Municipality, Cuba
}

\author{
Yolanda Díaz MS, Yairelis Espinosa
}

\begin{abstract}
In Cuba, alcohol is an important contributor to morbidity, mortality and social problems. The foundation of Cuba's universal primary health care coverage, family doctor-and-nurse offices play a critical role in prevention, early detection and treatment of alcohol abuse. Los Palacios Municipality of the westernmost province of Pinar del Río, Cuba, is a socially complex, periurban area where alcohol abuse and alcoholism have been identified as important health problems. Adolescents constitute a population at high risk for alcohol abuse because of their receptivity to social influences, but the precise extent of the problem is unknown. This paper reports baseline findings from a survey and direct observation of alcohol consumption in the catchment area of a primary care center, conducted to inform planning for an educational intervention.
\end{abstract}

KEYWORDS Alcohol, alcoholism, alcohol abuse, alcohol dependence, adolescence, primary health care, Cuba

\section{INTRODUCTION}

Approximately half the world's population consumes alcohol to some extent, divided into two groups: people who drink within social norms and people who exceed them (including alcoholics).[1]

Abuse of addictive substances, including alcohol, constitutes one of the great tragedies in today's world. Excessive alcohol use is one of the most common contributors to social problems such as unprotected sex, domestic violence, family abandonment, street fights resulting in injury, and job loss. Globally it is associated with $50 \%$ of traffic fatalities and $30 \%$ of murders and arrests (responsible for almost half of felony convictions). It reduces life expectancy by 10 to 15 years and is associated with $30 \%$ of psychiatric hospital admissions and some $8 \%$ of hospitalizations for psychosis.[2,3] When consumption exceeds social limits, it is a significant risk factor for cancer.[4,5]

In Cuba, alcohol is associated with one third of all crimes and $20 \%$ to $25 \%$ of deaths from unintentional injuries.[2,3] Data from other countries are also disturbing. In the United States 100,000 alcohol-related deaths are reported annually, and it is the leading cause of death in youth aged 15 to 16 years.[6] In Spain, alcoholism is the third leading cause of death. $[3,7]$

Magnus Huss coined the term alcoholism in 1849, and began to give a more human face to the phenomenon, viewing it as a disorder requiring medical treatment, rather than as a sin or moral failing.[1] WHO experts define alcoholism as a chronic behavioral disorder, with repeated bouts of alcohol use, excessive in terms of the community's dietary and social norms and that interferes with the drinker's health as well as economic and social functioning.[8] An estimated $10 \%$ of people who consume alcohol will eventually become alcoholics.[1] Timely diagnosis of excessive alcohol consumption helps prevent complications and progression to alcoholism, improving chances for better quality of life and full social integration.
Many countries fund extensive research on alcoholism and the stages leading to it, referred to variously as alcohol abuse, or nonsocial or harmful alcohol use.[2,7] By whatever name, as a serious health problem, it requires preventive and health-promoting actions to reduce patterns of excessive alcohol consumption and its consequences, actively involving all levels of health care in a multidisciplinary approach-starting at the primary level-as well as other sectors of society.[9]

Family doctor-and-nurse offices play a central role in Cuba's universal primary health care coverage, each responsible for serving approximately 1200 persons in their geographic catchment area, the latter ranging from urban to periurban to rural settings. They play a fundamental role in early diagnosis of alcoholism and nonsocial drinking, and even more important, alcoholism prevention through community education. Embedded in the community, the family doctor and nurse can detect excessive consumers headed toward alcoholism and alert them and their families to its risks, using various health education techniques and supported by mental health professionals and facilities.[10-12] The latter include community mental health centers that deliver various programs and services, including alcoholism treatment, with activities ranging from health promotion to rehabilitation of alcoholic persons.[13]

In Cuba, $45.2 \%$ of the population aged $>15$ years consumes alcohol. The reported prevalence of alcoholism is from $7 \%$ to $10 \%$ among the lowest in Latin America-predominantly in the group aged 15 to 44 years. However, in the last 15 years consumption has increased appreciably. High-risk consumption patterns exist as well as a tolerant attitude toward alcohol abuse. It is calculated that alcoholism treatment may consume some $40 \%$ of emergency service resources and that $2 \%$ of hospital admissions are related to or aggravated by alcohol abuse.[2]

According to $\mathrm{WHO}$, adolescence comprises the ages 10 through 19 years.[8] It is a sensitive period for consumption of addictive substances, which if not well managed can continue through adulthood, detrimental to the individual, family and society at large. Excessive alcohol consumption by young people is a major health problem today, and has become a priority in many countries.[14,15] In Cuba, $90.4 \%$ of the alcohol-consuming population began drinking before the age of 25.[2]

In Los Palacios Municipality of the westernmost province of Pinar del Río, Cuba, alcohol abuse and alcoholism have been identified as important health problems. Family doctors have identified 571 alcoholics and 7861 high-risk consumers in a population of 38,786.[16] There may be underreporting, especially in adolescents and young adults. In fact, periurban zones, such as those included in Los Palacios, have been identified as socially complex areas in which precise prevalence of alcoholism in adolescents is unknown. At the same time, these youth constitute a high-risk population because of their stage of development, characterized by receptivity to influences from the social environment. 
Family doctor-and-nurse office No. 28 is located in one of these socially complex areas. In exploratory work, we observed alcohol abuse and consumption leading to intoxication (mainly among adolescents and youth in public places) and frequent brawls among drinkers. What emerged, then, was how to characterize alcohol-related behavior in the adolescents within our catchment area as a foundation for action. Hence, the current study, which will inform planning for an awareness workshop aimed at heightening risk perception related to alcohol abuse, thus contributing to prevention.

\section{METHODS}

We conducted a cross-sectional survey of adolescent alcohol consumption during March and April 2010. From a total of 187 adolescents aged 10 through 19 years in office No. 28's catchment area of Los Palacios Municipality, we used stratified sampling to obtain a representative sample of both sexes, which included 109 adolescents. The survey instrument incorporated the diagnostic indicators questionnaire (CID, the Spanish acronym) and CAGE questionnaire,[2,17] both validated for research on alcoholism, to determine prevalence of alcohol consumption and collect information on other variables, such as age the individual started drinking, drinking motivation and most common types of alcohol consumed.

Definition of alcohol abuse (criteria according to González)[1]

- Quantity/frequency criterion: Consumption $\geq 3$ times per week the equivalent of a quarter bottle of a hard liquor (rum), one bottle of wine or 2.5 bottles of beer-quantities representing 30 to 100 grams of alcohol each day of consumption-or when the individual experiences at least 12 episodes of light intoxication over a single year.

- Harmful or toxic criteria: Harmful effects of alcohol occurring repeatedly in any domain: biological (gastritis, hepatitis, pancreatitis, polyneuritis), psychological (depression, anxiety, guilt, dysphoria) or social (loss of employment, separation or divorce, arrest).

- Dependency criterion: Progressive loss of freedom of choice regarding alcohol. This may be manifested in three ways: loss of control, when the individual cannot stop once he/she begins to drink; inability to abstain, when the individual cannot go for more than two days without drinking; and daily need for alcohol, when the subject needs to drink to be able to function.

Study variables are summarized in Table 1.

Using a structured guide, the authors observed adolescents' alcohol consumption behavior in their social environment as well as availability of appropriate opportunities for healthy recreation, such as alcohol-free party venues, sports centers and cultural activities. When adolescents' behavior was the object of observation, it continued on several occasions until each aspect observed reached saturation, that is, when it was sufficient to identify repetitive behavior. Observation to identify places and events was done only once.

We used descriptive statistics to organize and classify indicators obtained in the assessment through frequency distribution tables and measures of central tendency.

The board of directors of the Los Palacios Community Mental Health Center approved the research. Written informed consent was obtained from participants and, if aged $<16$ years (Cuban age of majority), from parents or guardians.
Table 1: Study variables

\begin{tabular}{|c|c|}
\hline Variable & Description \\
\hline $\begin{array}{l}\text { Age group } \\
\text { (years) }\end{array}$ & $\begin{array}{l}\text { 10-13 (early adolescence) } \\
14-16 \text { (mid-adolescence) } \\
17-19 \text { (late adolescence) }\end{array}$ \\
\hline Sex & $\begin{array}{l}\text { Male } \\
\text { Female }\end{array}$ \\
\hline
\end{tabular}

Alcohol-related Abstinent: Never consumes

behavior[1] Rarely consumes:

- Consumes only rarely and only on special occasions

- $\leq 1$ drink per occasion

- $\leq 5$ times per year

Consumes socially:

- Consumes on specific occasions, birthdays, parties and holidays

- $1 / 4$ bottle of rum or its equivalent in wine (1 bottle) or beer ( 2.5 bottles) on each occasion

- Does not exceed social norms

At risk:

- Exceeds social consumption but not to point of harm

Harmful:

- Manifests harmful effects (biopsychosocial)

- Consumes almost daily $>1 / 4$ bottle of rum, $>1 / 2$ bottle of beer, $>1$ bottle of wine

- Becomes intoxicated more than once a month or $>12$ times a year

Active alcoholic:

- Exceeds limits above

- Has lost all choice concerning alcohol consumption

\begin{tabular}{l|l}
$\begin{array}{ll}\text { Motivations } \\
\text { for drinking }\end{array}$ & $\begin{array}{l}\text { Spend free time } \\
\text { Accompany friends or neighbors } \\
\text { Gain others' respect and approval } \\
\text { To relax, gives me courage to express what I feel } \\
\text { Cheers me up, gives me strength } \\
\text { To imitate people I love or admire } \\
\text { I like alcohol's effect and taste } \\
\text { Other }\end{array}$ \\
\hline Type of drink & $\begin{array}{l}\text { Beer } \\
\text { Rum }\end{array}$ \\
& $\begin{array}{l}\text { Wine } \\
\text { Home brew }\end{array}$ \\
\hline Length of time & $<1$ month \\
individual has & $1-6$ months \\
been drinking & $>6$ months-1 year \\
& $>1$ year \\
\hline Age started & $10-13$ \\
drinking & $14-16$ \\
(years) & $17-19$ \\
\hline $\begin{array}{l}\text { Family/friends } \\
\text { who consume } \\
\text { alcohol }\end{array}$ & $\begin{array}{l}\text { Mother } \\
\text { Father } \\
\text { Siblings and close family }\end{array}$ \\
\hline & Neighbors \\
\hline
\end{tabular}

\section{RESULTS}

Of the 109 young people studied, 73 (67\%) consumed alcohol (Table 2). This indicates a high rate of alcohol consumption; these adolescents drink in their free time, in company of friends and neighbors, which is corroborated by our observations that young people frequently gather in groups to drink on the street. Our observations also suggest that conditions in the area, characterized by extremely limited recreational resources, do not support healthy and fun activities for young people, a factor that predisposes to 
drinking.[18] These results are similar to those reported in a study in Havana,[18] as well as in other countries, where the statistics are alarming. In Colombia, for example, alcohol is inextricably bound to the country's social life, and in Mexico nearly 27 million people aged 12 to 65 years drink excessively, while drinking begins at ever younger ages.[19]

Social consumption was more common in young women than in young men $(18 / 54,33.3 \%$ vs. $10 / 55,18.2 \%$, respectively). Notably, some $18.2 \%(10 / 54)$ of male adolescents and $14.8 \%(5 / 55)$ of female adolescents were in the at-risk consumption category. This is a worrisome pattern, since it suggests an important proportion of youth poised to move to harmful levels of consumption, with potential for progressive bio-psychosocial damage that can harm the adolescent and his/her environment, and lead to chronic use and alcoholism (Table 2).

Table 2: Alcohol-related behavior* by sex and age $(n=109)$

\begin{tabular}{|c|c|c|c|c|c|}
\hline \multirow[b]{2}{*}{ Distribution } & \multicolumn{5}{|c|}{ Alcohol use } \\
\hline & $\begin{array}{c}\text { Abstinent } \\
\text { n (\%) }\end{array}$ & $\begin{array}{l}\text { Rare } \\
\text { n (\%) } \\
\end{array}$ & $\begin{array}{l}\text { Social } \\
\text { n (\%) }\end{array}$ & $\begin{array}{c}\text { At risk } \\
\text { n (\%) }\end{array}$ & $\begin{array}{l}\text { Total } \\
\text { n (\%) } \\
\end{array}$ \\
\hline \multicolumn{6}{|l|}{ By sex } \\
\hline Male & $20(36.4)$ & $15(27.3)$ & $10(18.2)$ & $10(18.2)$ & $\begin{array}{r}55 \\
(100.0)\end{array}$ \\
\hline Female & $16(29.6)$ & $12(22.2)$ & $18(33.3)$ & $8(14.8)$ & $\begin{array}{r}54 \\
(100.0)\end{array}$ \\
\hline Total & $36(33.0)$ & $27(24.8)$ & $28(25.7)$ & $18(16.5)$ & $\begin{array}{r}109 \\
(100.0)\end{array}$ \\
\hline \multicolumn{6}{|c|}{ By age group (years) } \\
\hline $10-13$ & $24(54.6)$ & $11(25.0)$ & $7(15.9)$ & $2(4.5)$ & $44(100)$ \\
\hline $14-16$ & $7(26.9)$ & $4(15.4)$ & $8(30.8)$ & $7(26.9)$ & $26(100)$ \\
\hline $17-19$ & $5(12.8)$ & $12(30.8)$ & $13(33.3)$ & $9(23.1)$ & $39(100)$ \\
\hline Total & $36(33.0)$ & $27(24.8)$ & $28(25.7)$ & $18(16.5)$ & 109 (100) \\
\hline
\end{tabular}

*No adolescents in categories of harmful use or active alcoholism

We noted that the proportion of abstainers decreased with increasing age, and as expected, prevalence of drinking was highest in the oldest group, aged 17 to 19 years. This was not, however, the group with the highest prevalence of at-risk drinking, which was found in the group aged 14 to 16 years. Worse and alarming, two at-risk drinkers were identified in the group aged 10 to 13 years (Table 2). Similar results have been found elsewhere; for example, a study in a Mexican high school reported excessive alcohol consumption beginning at ever younger ages.[20]

Beer was the most frequently consumed form of alcohol in our sample $(76.7 \%, 55 / 73)$, a finding of concern on two counts. First, beer is rather expensive in Cuba, and this finding may imply a certain permissiveness on the part of parents, since most adolescents are still economically dependent. Second, because of its lower alcohol content, an individual can consume more before experiencing negative effects, and this can reinforce the drinking habit. $[1,3]$ Beer was also the most common alcoholic drink consumed by adolescents in studies in a medical clinic in Havana[18] and in Mexico.[20]

Wine was the second most common alcoholic drink $(72.6 \%$, $53 / 73)$, followed by rum $(42.5 \%, 31 / 73)$, suggesting that adolescents are consuming drinks that are more expensive in today's market (rum, Cuba's iconic drink, is cheapest). The least popular form of alcohol was home brew $(27.4 \%, 20 / 73)$. Homemade alco- hol can be more damaging to health, since the alcohol content tends to be higher and its production is not subject to public health controls.[1]

The majority $(87.7 \%, 64 / 73)$ of adolescents who drank had been intoxicated at least once. More than half $(53.4 \%, 39 / 73)$ said they started to drink only recently, in the previous few months, but at least $26 \%$ (19/73) had already been drinking for almost a year.

The 73 adolescents who consumed alcohol reported that their friends, parents and people closest to them drank alcohol. Because of the affective importance the minor assigns to these figures, they serve as powerful behavioral models and can play a key role in adolescent drinking initiation. These results coincide with those of research conducted in Havana,[18] which also noted that most drinkers began when they were aged $<20$ years and were classified as at-risk consumers. In an urban high school study of 315 adolescents in Mexico[20], risky consumption was found in $17.1 \%$ and harmful consumption in $1.9 \%$; 85 said that one of their parents consumed alcohol often $(27 \%)$ and $65(20.6 \%)$ reported that the parent did so to the point of intoxication.

The most common motivations for alcohol consumption in those we surveyed were to accompany friends or neighbors $(57.5 \%)$ and to pass their free time (24.7\%), which could be associated with the lack of entertainment and few options for recreation in alcohol-free community settings; a finding consistent with our observations.

We observed young people drinking alcohol on sidewalks and streets especially on weekend afternoons and nights, displaying aggressive attitudes on several occasions, and disturbing other residents. Alcohol consumption was also observed on weekday afternoons and evenings, but by fewer people than on weekends. Young groups of both sexes also gathered and drank at locations where alcohol was sold; adults were occasionally observed with them.

\section{LESSONS LEARNED}

Prevalence of alcohol consumption among the adolescents studied was high and increased with age, but it was the group aged 14 to 16 years that had the highest rate of at-risk use.

Drinking patterns were already established in adolescence in both men and women, which is worrisome from a social and health perspective, both for current and adult behavior and consequences.[2]

We confirmed that few options for healthy (alcohol-free) entertainment (parties, sports facilities, cultural events) exist in this community. Addressing this situation requires involvement by sectors of society beyond the health sector.

Adults among the adolescents' family and friends modeled drinking behavior and possibly facilitated acquisition of relatively expensive beverages.

The authors concluded that a multisectoral analysis of this problem is required, associated with various actions at the community level. From the perspective of the health sector, a feasible first step could be a proposal, informed by these results, for an aware- 
ness workshop for the catchment area population, aimed at discouraging consumption.

\section{RECOMMENDATIONS}

Inappropriate alcohol consumption in adolescence is an important challenge for government and social organizations, as well as for health institutions, one that will require multisectoral action to prevent alcohol abuse and reduce alcoholism in the community.

The authors recommend conducting a community alcoholawareness workshop, serving as a pilot for extension to other similar communities. Such a workshop should be designed to be attractive to adolescents and the general community, with readily understandable messages. Given this, we propose involvement by adolescents themselves in developing the workshop, or series of workshops, that might begin with a play or other format to address topics such as myths and prejudices about alcoholism, phases in developing alcohol dependence, and characteristics and consequences of irresponsible consumption.

This could be followed by a neighborhood debate, promoting dialogue and participation by all, in which adolescents and their families can express concerns, doubts and anxieties, and receive clarification on misconceptions. It is hoped that such an approach would provide space for reflection and internalization of this serious social and health concern, leading to elaboration of a collective response.

\section{REFERENCES}

1. González Menéndez R. Alcoholismo. Abordaje integral. Santiago de Cuba (CU): Editorial Oriente; 2006. p 14-154. Spanish.

2. García Gutiérrez E, Lima Mompó G, Aldana Vilas L, Casanova Carrillo P, Feliciano Álvarez V. Alcoholismo y sociedad, tendencias actuales. Rev Cubana Med Milit [Internet]. 2004 [cited 2012 Aug 27];33(3). Available from: http://bvs.sld.cu/ revistas/mil/vol33_3_04/mil07304.htm. Spanish.

3. González Menéndez R. Las adicciones ante la luz de las ciencias y el símil. Havana: Editorial Política; 2009. p. 67-132. Spanish.

4. González Méndez R. El uso no social de alcohol como factor de riesgo oncológico. Rev Cubana Salud Pública. 2011;37(Suppl.):686-94. Spanish.

5. Brito Sosa G, Iraizos Barrios AM. Repercusión social y análisis bioético del alcoholismo en pacientes del Grupo de Alcohólicos Anónimos de La Habana. Rev Cubana Med Gen Integr. 2011;27:3. Spanish.

6. Gutiérrez E, Bandera A, Gómez AM, Galiano MC, Aquino JR, Aneiros R, et al. Toxicomanía y adolescencia: realidades y consecuencias [Internet]. Havana: Ministry of Public Health (CU); 1999 Jul. 88 p. Available from: http://www.sld.cu/ libros/libros/libro5/toxicolo.pdf. Spanish.

7. Preuss UW, Schuckit MA, Smith TL, Danko GR, Dasher AC, Hesselbrock MN, et al. A comparison of alcohol-induced and independent depression in alcoholics with histories of suicide attempts. J Stud Alcohol. 2002 Jul;63(4):498-502.

8. Organización Mundial de la Salud: Glosario y guía para la clasificación de trastornos mentales y del comportamiento según la $\mathrm{X}$ Revisión de Clasificación internacional de enfermedades. Madrid: Meditor. 1992. p. 25-39. Spanish.

9. Oliva Agüero C, Clavijo Portieles A. Alcoholismo y adicciones su manejo en la atención primaria de salud. In: Álvarez Sintes R, editor. Medicina General Integral. Havana: Editorial Ciencias Médicas; 2008. Chapter 109. p. 295-311. Spanish.

10. Cortés Torres D, Gorrita Pérez R, Alfonso Hernández L. Patrones de consumo relacion- ados con el alcohol en la población masculina de un consultorio. Rev Cubana Med Gen Int. 2005;102:275-83. Spanish.

11. Sarmiento Ducónger $R$, Carbonell García IC, Plasencia Asorey C, Ducónger Castellanos R. Patrones de consumo de alcohol en una población masculina de El Caney. MEDISAN [Internet]. 2011 Apr [cited 2012 Aug 27];15(4):495-502. Available from: http://scielo .sld.cu/scielo.php?script=sci arttext\&pid=S1029 $-30192011000400014 \&$ Ing=es. Spanish.

12. Morales M, Del Prado M, Del Prado A. La Familia en la Rehabilitación Social de Pacientes Alcohólicos. Experiencias en el Municipio Santiago de Cuba. Santiago [Internet]. 2010 (123):1-21. Available from: http://ojs.uo.edu.cu/index.php/ stgo/article/view/45100303/2290. Spanish.

13. Jara J. Sexo, alcohol y adolescentes. Rev Médica ABIMAD [Internet]. 2005 Nov [cited 2010 Jul 25];(58). Available from: http://www.abimad .org/documentaci\%C3\%B3n-por-temas/10 -\%C3\%A9tica-y-adolescencia/sexo-alcohol-y -adolescentes/. Spanish.

14. Barcos Pina I, Álvarez Sintes R. Atención al adolescente. In: Álvarez Sintes R, editor. Medicina General Integral. Havana: Editorial Ciencias Médicas; 2008. p. 247-53.

15. Montano Luna JA, Prieto Díaz VI. Enfoque preventivo y factores de riesgo. En: Álvarez Sintes R, editor. Medicina General Integral. Havana: Editorial Ciencias Médicas; 2008. p.168-75.

16. Informe de Balance del Centro Comunitario de Salud Mental. Departamento de Estadística Municipal de Salud. Los Palacios. Pinar del Río (CU): Provincial Health Statistics Bureau; 2009. Spanish.

17. González Méndez R. La atención integral al alcoholismo: experiencia cubana. Rev Cubana Med [Internet]. 2008 [cited 2010 Aug 15];47(2). Available from: http://scielo.sld.cu/scielo.php?pid=S0034 $-75232008000200012 \&$ script=sci arttext. Spanish.

18. Campillo Motilva R, Vizcay Basabe V. Caracterización del consumo de bebidas alcohólicas en adolescentes de un consultorio médico.
Rev Cubana Med Gen Int. 2003;19(3):17-23. Spanish.

19. Bosque J, Fernández $C$, Fuentes A, Díaz DB Espínola M, González N, et al. Hacia una mejor respuesta ante el problema del abuso de bebidas con alcohol: el papel del Sector Salud. Salud Mental [Internet]. 2012 [cited 2010 Aug 15];35:165-74. Available from: http://www.medi graphic.com/pdfs/salmen/sam-2012/sam122j .pdf. Spanish.

20. Sánchez IA, Roa V, Gómez C, RodríguezOrozco A. Prevalencia de consumo riesgoso y dañino de alcohol en adolescentes de una escuela preuniversitaria urbana de Morelia. Rev Cubana Pediatr [Internet]. 2008 Oct-Dec [cited 2012 Aug 27];80(4). Available from: http://scielo .sld.cu/scielo.php?script=sci_arttext\&pid=S0034 $-75312008000400005 \&$ Ing $=$ es. Spanish.

\section{THE AUTHORS}

Yolanda Díaz Castro (Corresponding author: yolandadiaz@princesa.pri.sld.cu),psychologist with a master's degree in comprehensive child health, Los Palacios Community Mental Health Center. Associate professor, Medical University of Pinar del Río, Los Palacios satellite campus, Pinar del Río, Cuba.

Yairelis Espinosa Ferro, psychologist, Los Palacios Community Mental Health Center. Instructor, Medical University of Pinar del Río, Los Palacios satellite campus, Pinar del Río, Cuba.

Submitted: June 26, 2012

Approved for publication: March 30, 2013 Disclosures: None

\section{ERRATA}

Aragonés C, Campos JR, Pérez D, Martínez A, Pérez J. SIDATRAT: Informatics to Improve HIVIAIDS Care. MEDICC Rev. 2012;14(4):5-9. Page 7, Figure 2, label for the second graphic should be "Viral load."

Armas NB, Ortega Y, de la Noval Reinaldo, Suárez R, Llerena L, Dueñas AF. Acute Myocardial Infarction Mortality in Cuba, $1999-2006$. MEDICC Rev. 2012;14(4):19-24.

Page 21, first paragraph, the first sentence, out-of-hospital deaths should be $54.8 \%$ of total for $1999-2003$ and $59.2 \%$ for $2004-2008$.

Page 23, Figure 5, out-of-hospital deaths should be $56.9 \%$ of total for both periods combined. 